\title{
SUB-BOTTOM FEATURES AND PHYSICAL PROPERTIES OF WATER OF THE TANGALLE BAY, SRI LANKA
}

\author{
SHANAKA MADURANGA WETHTHASINGHE ${ }^{1 *}$, AMILA $^{*}$ \\ SANDARUWAN RATNAYAKE ${ }^{2}$, NIMILA DUSHYANTHA ${ }^{1}$, NALIN \\ PRASANNA RATNAYAKE ${ }^{1}$, G.V. I. SAMARADIVAKARA ${ }^{1}$, A.V.P. \\ VIJITHA ${ }^{1}$ \\ ${ }^{1}$ Department of Earth Resources Engineering, Faculty of Engineering, University \\ of Moratuwa, Moratuwa, Sri Lanka \\ ${ }^{2}$ Department of Mineral Resources and Technology, Uva Wellassa University, \\ Passara Road, Badulla, Sri Lanka \\ ${ }^{*}$ Corresponding Author Email: shanmadu077@gmail.com
}

(Received $31^{\text {st }}$ May 2018; accepted $08^{\text {th }}$ September 2018)

\begin{abstract}
Monitoring of physical properties of water and local coastal geomorphological features are vital proxies to sustainable coastal management activities. In this study, sub-bottom features and water quality parameters were investigated in the Tangalle Bay during the northeast monsoon. Systematic sampling was carried out for covering three cross-shore and six longshore survey lines. Temperature variations displayed a thin epilimnion layer (i.e., about $3 \mathrm{~m}$ warm water) up to $4 \mathrm{~km}$ distance from the shoreline. The variation of temperature also suggested that the deeper and distance area was characterized by extremely well-mixing nature. Similarly, high dissolved oxygen values (range from 7.5-8.0 ppm) suggested well mixing/circulation pattern of marine water. These observations were further supported by sand-rich, well oxidized and organic matter poor surface sediment of the study area. Salinity values (range from 33.4 to $33.8 \mathrm{ppt}$, average $=33.6 \pm 0.14$ ) are relatively low due to the supply of a significant amount of freshwater. Sub-bottom survey indicated that the attached coral reef to the bedrocks can generate two different depositional environments. It was followed by deposition of unconsolidated and homogenous sediments separately, possibly from two different sources.
\end{abstract}

Key words: Tangalle Bay, Physical properties of water, Sri Lanka Sub-bottom morphology,

\section{INTRODUCTION}

Global climate is forcefully influenced by coastal geomorphological changes in the tropical region. This is greatly relevant to the issues during the Anthropocene that experience rising of $\mathrm{CO}_{2}$ and temperature (Kirwan and Megonigal, 2013; Nicholls and Cazenave, 2010). Sediment transport, shoreline migration, seawater intrusion and water chemistry variations are dynamic processes in coastal aquatic systems related to geomorphological changes (Van Rijn, 2011; Jayawardana et al., 2012; Zhou et al., 2014; Dubois et al., 2018). These processes interact with existing coastal aquatic system over a variety of time and spatial scales. Therefore, understanding of physicochemical and morphological changes in coastal systems is important to monitor biological processes and to understand geological changes (Jayawardana et al., 2012; Ratnayake et al., 2017b, 2018a). In fact, the case 
studies of reef topography, bathymetric data, suspended sediments in coastal waters and shoreline changes are also remarkably important to construct hard engineering structures such as seawalls, wave breakers, groyne and harbors (Ratnayake et al., 2018b). Coastal deterioration such as erosion negatively affects tourism-based economy of Sri Lanka due to limits public beach access, and damages homes/infrastructure and ecology. So far, few studies have been carried out in Sri Lanka for identifying physicochemical changes and subbottom profiles in coastal zones (e.g., Ratnayake et al., 2013). In addition, our present understandings of coastal processes are limited by the instrumental records, especially in the south coast of Sri Lanka. The island of Sri Lanka belongs nearly $1550 \mathrm{~km}$ of coastal line stretch with a variety of geomorphological features such as bays, lagoons, headlands, etc. The continental shelf is particularly narrow to the west to south coasts, widening to the northwest to north coasts (Cooray, 1984). Many of the coastal lines are seasonally dominated by the high wave energy in the southwest and northeast monsoons. It can follow the changes of physicochemical parameters and coastal geomorphology (Van Rijn, 2011; Jayawardana et al., 2012; Zhou et al., 2014). The objective of this case study is to identify the variability of the physical properties of water (i.e., dissolved oxygen, salinity, temperature and density) in the Tangalle Bay, as a monitoring program. The authors also investigate shallow depth sub-bottom conditions of the Tangalle Bay using geophysical investigations.

\section{STUDY AREA}

The Tangalle Bay is located at the most southern part of Sri Lanka (Figure 1). The Rekawa Lagoon is also located adjacent to the Tangalle Bay. Tangalle is one of the famous tourist destinations for watching sea turtle and corals in the southern coast of Sri Lanka. However, the literature studies suggested that corals in the Tangalle Bay are partially degraded due to sedimentation and anthropogenic activities (Rajasuriya and White, 1995). Coastal tourism plays an important role presently around the study area as employment and income for locals. In addition, another important economic activity of the study area is catching of live fish species existing around corals for ornamental purposes and trading. Several tourist hotels are located along the beach of the Tangalle Bay causing environmental changes to the naturally existing ecosystems. The study area experiences the dominant ocean waves during the southwest monsoon (Figure 1). Therefore, seasonal sand deposition and erosion at the estuary mouth can significantly control variation of physicochemical parameters such as salinity in the Rekawa Lagoon. Two branches of Kirima Oya stream fall into the bay and feed by sediments. Several breakwaters and groins are constructed in the Tangalle Bay to prevent the coastal erosion.

\section{MATERIALS AND METHODS}

Field excursion of the Tangalle Bay was carried out using the Samudrika vessel (belongs to the Ocean University of Sri Lanka) in February, 2017. In this period, the study area is relatively calm due to weak northeastern monsoon influence along the southern coast of Sri Lanka. Systematic sampling $(\mathrm{n}=18)$ was carried out to measure water quality parameters using Valeport Midas CTD instrument. It incorporates the physical properties of water such as temperature, depth, salinity, dissolved 
oxygen, and water density. Dissolved oxygen level was calculated using the oxygen saturation scale of $100-108 \%$ at $30{ }^{\circ} \mathrm{C}$ (Mortimer, 1956). The recorded data of CTD instrument was extracted and used to draw water quality parameter profiles along the survey lines. In contrast, surface sediments samples were collected from same sampling locations using an Ekman-Berge type grab sampler.

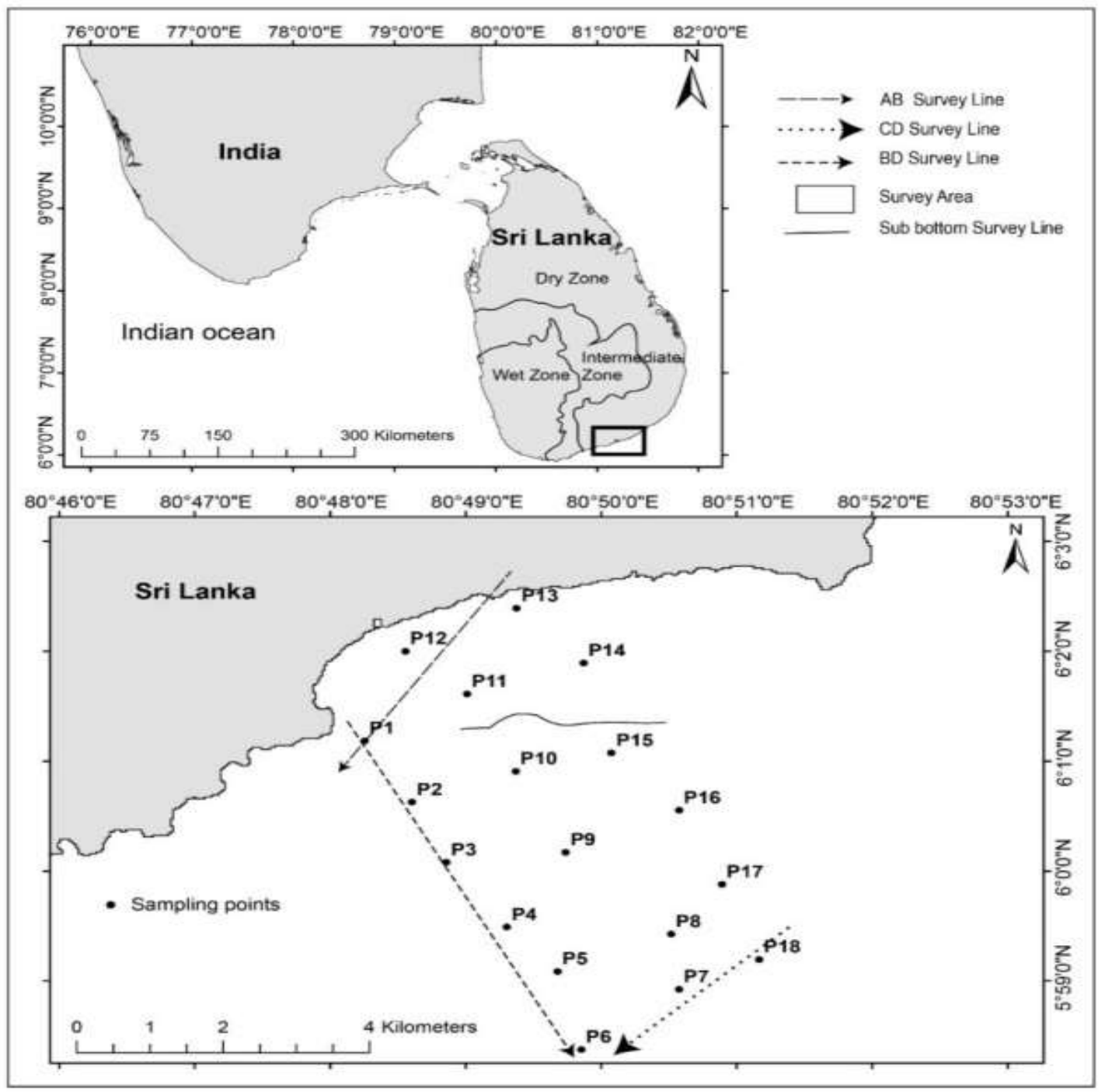

Fig. 1 Map of Sri Lanka showing the Tangalle bay and sampling point.

All sampling sites were plotted on a digital map and Global Position System (GPS) was used to select desired locations during the field works. Sampling area was covered about $7 \mathrm{~km}$ maximum distance from the shoreline and about $4 \mathrm{~km}$ width of the Tangalle Bay. In addition, it included three cross-shore and longshore survey lines.
GPS coupled Bathy 2010PCTM CHIRP sub-bottom profiler (frequency $3.5 \mathrm{kHz}$ ) and bathymetric echo sounders (frequency $210 \mathrm{kHz}$ ) were used to understand sub-bottom conditions and bathymetry, respectively. The details of the instrumental handling procedures were described by Ratnayake et al. (2017a). 


\section{RESULTS AND DISCUSSION \\ BATHYMETRY AND SUB-BOTTOM CONDITION}

Figure 2 shows the bathymetry map of the Tangalle Bay. The water depths of the study area range from $6 \mathrm{~m}$ to $37 \mathrm{~m}$. The authors calculated slope angle considering depth and distance along cross-shore survey lines. The average shelf slope angle is approximately $0.3^{\circ}$ degrees (i.e., $6 \mathrm{~m}$ depth range per $1 \mathrm{~km}$ of distance).
Surface samples mainly consist of sand particles with coral fragments and shells. Organic matter preservation is poor in surface sediment may be due to a well-oxidized bottom condition (Müller and Suess, 1979; Hedges and Keil, 1995; Sampei et al., 1997). Several isolated coral reef patches can be identified during the collection of surface sediment samples, as discussed under sub-bottom profile data.

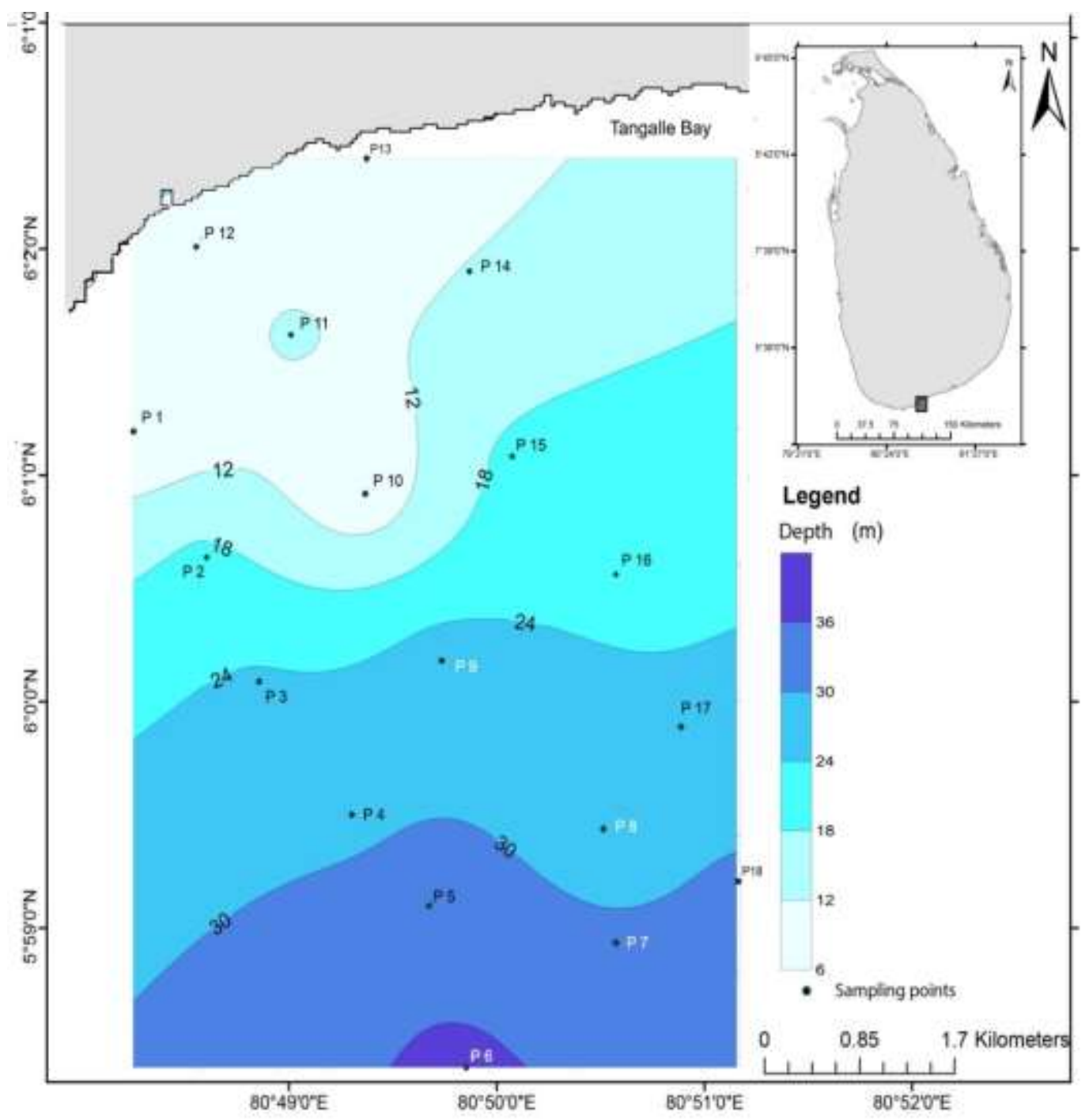

Fig. 2. The simplified bathymetry map of the study area. 
Figure 3 indicates sub-bottom features along the representative survey line of the Tangalle Bay. It provides highresolution penetration images up to $\sim 20 \mathrm{~m}$ in depth.

In this study, sub-bottom profiler data clearly indicate the attached coral reef on to the bedrock of the oceanic bottom (Figure 3). The echogram shows that the attached coral reef creates two depositional environments along this survey line. One side of the reef consists of layered sedimentary structures. However, the opposite side is characterized by the distribution of homogeneous sediments (Figure 3). In addition, it can indicate two different sources such as marine and terrestrial
(Seibold and Berger, 1996). Therefore, sediment distribution of the study area can be controlled by isolated patches of coral reef.

\section{PHYSICAL PROPERTIES OF WATER}

The longshore water column profiles along the shallow depth ( $\mathrm{AB}$, including sampling sites $\mathrm{P} 1, \mathrm{P} 12$ and $\mathrm{P} 13$ ) and high depth (CD, including sampling sites P5, P8 and P17) survey lines are shown in Figure 4 and 5, respectively. The cross-shore water column profile (including sampling sites from P1 to P6) is shown in Figure 6. Table 1 shows the summary of physical parameter data of each survey lines.

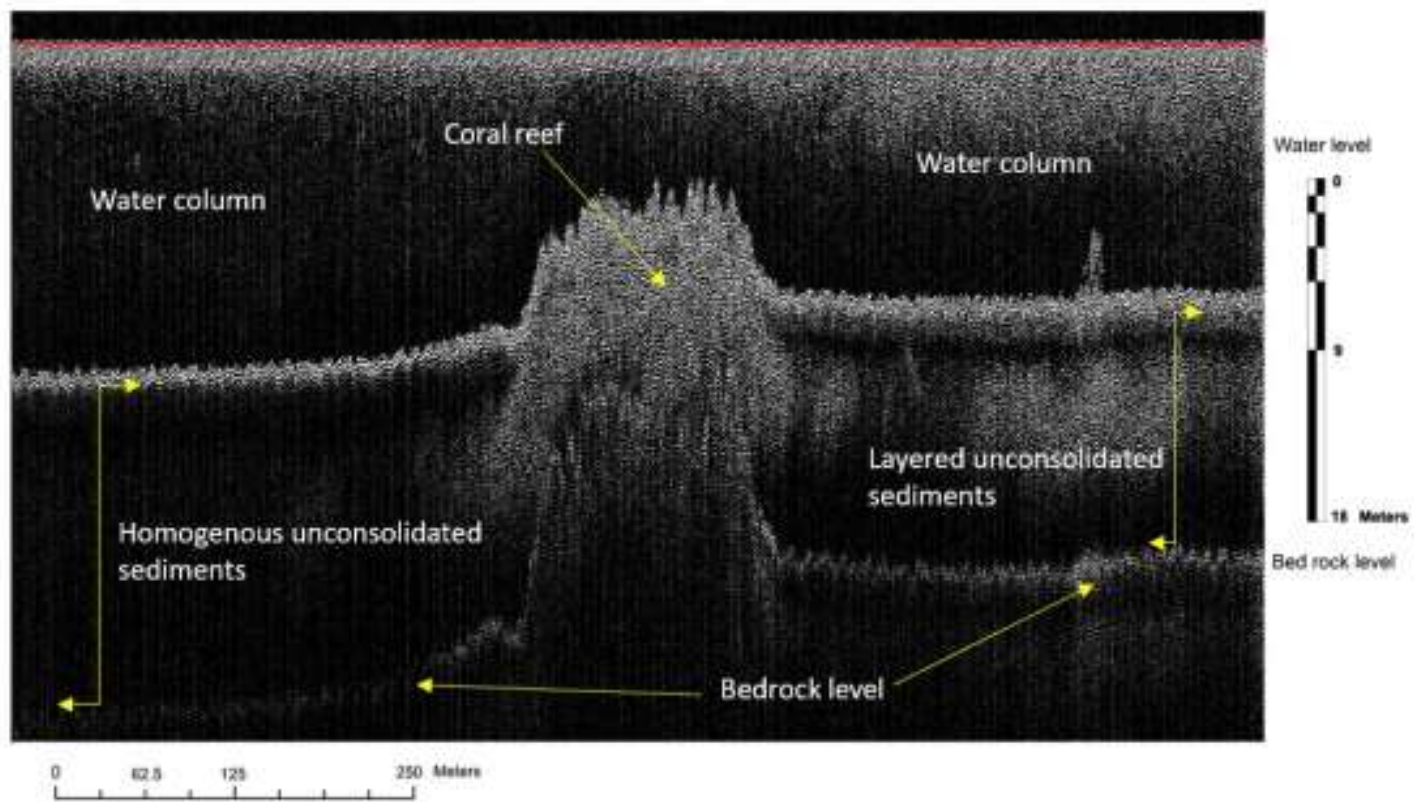

Fig. 3. The echogram shows sub-bottom condition along the survey line.

\section{TEMPERATURE}

Temperature values generally range between $27^{\circ} \mathrm{C}$ to $30^{\circ} \mathrm{C}$. Temperature is measured digitally as a function of pressure. Figure 4 and 5 indicate that relatively high temperature on the surface and a little decrease in the depth along cross-shore survey lines. It can indicate a reduction of sunlight penetration on the surface of the sea water. However, in this study, the strong thermal stratification cannot be observed due to well-mixing and wellcirculation nature under the tropical condition. On the other hand, ocean waves and wind actions can cause turbulent mixing of the top layer and bring temperature equal value. According to longshore survey lines, 
the epilimnion (i.e., warm layer) is limited to 2-3 $\mathrm{m}$ in depth. In contrast, the cross-shore survey lines show that the epilimnion (the maximum depth < $4 \mathrm{~m}$ ) is limited to shallow water, up to $4 \mathrm{~km}$ distance from the shoreline (Figure 6). Consequently, the oceanic mixed layer depth of the study area is very shallow. The oceanic mixed layer makes a connection between atmosphere and ocean. In addition, it holds high heat capacity compared to the atmosphere above. The mixed layer thus plays a significant role in climate variability (Carton and Giese, 2008).

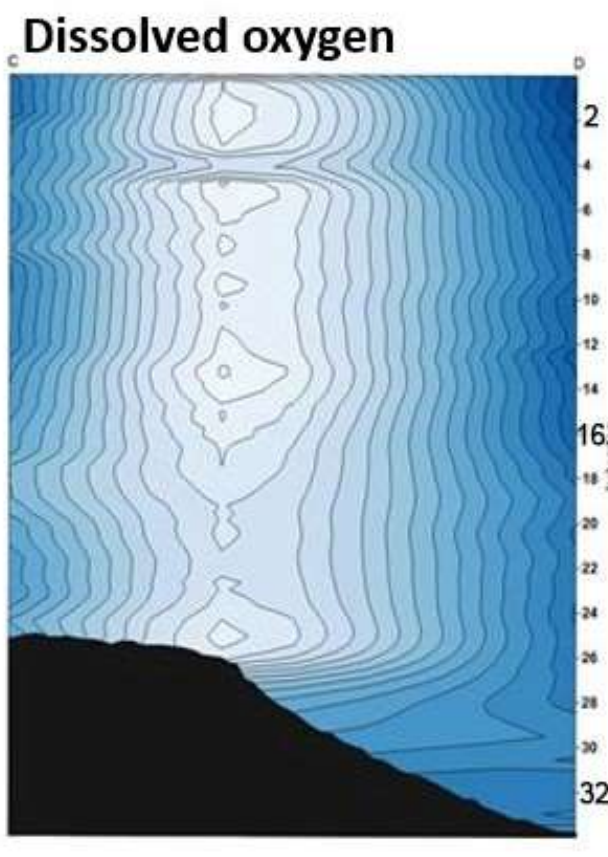

\section{Temperature}

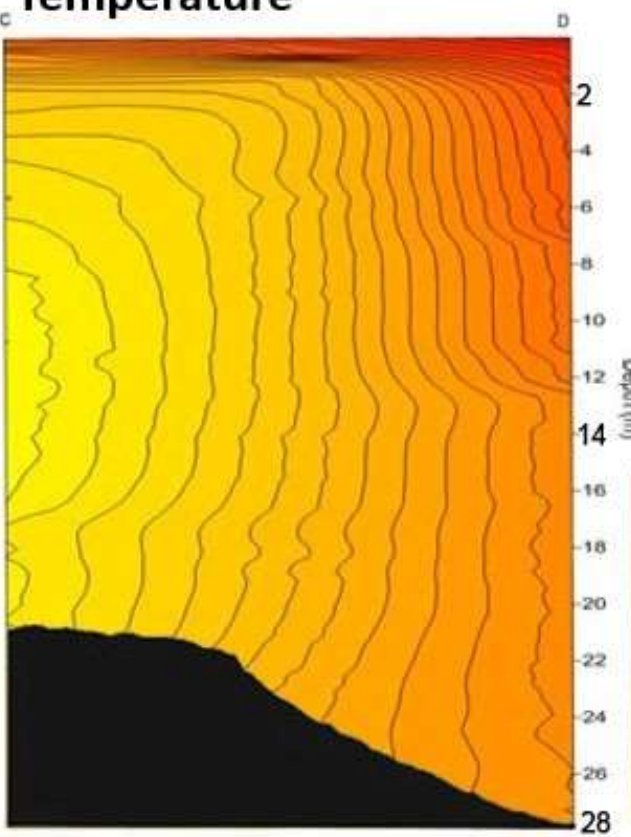

\section{Salinity}

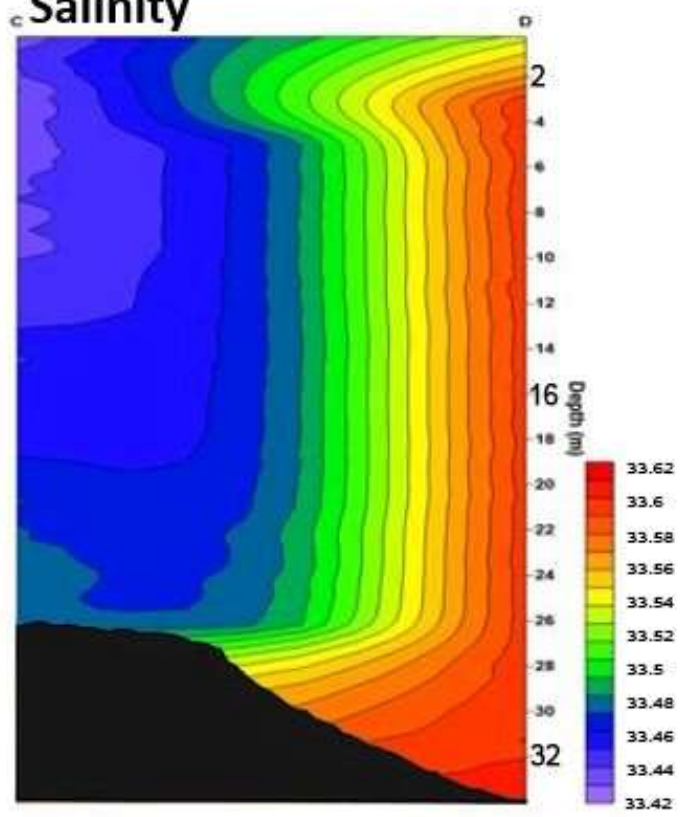

Density

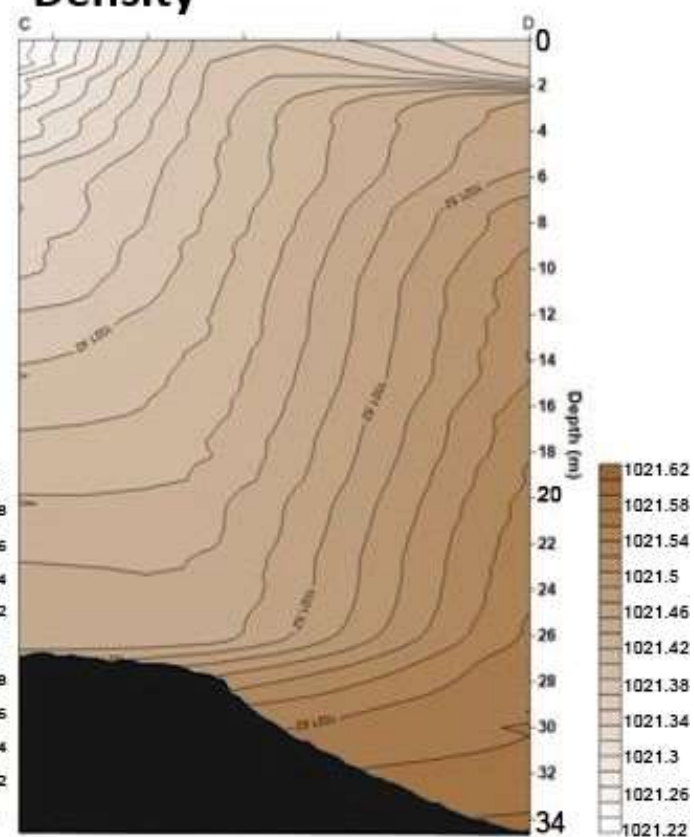

Fig. 4. The longshore survey profile along the shallow depth (AB, including sampling sites $\mathrm{P} 1, \mathrm{P} 12$, and $\mathrm{P} 13$ ) shows physicochemical variations. 

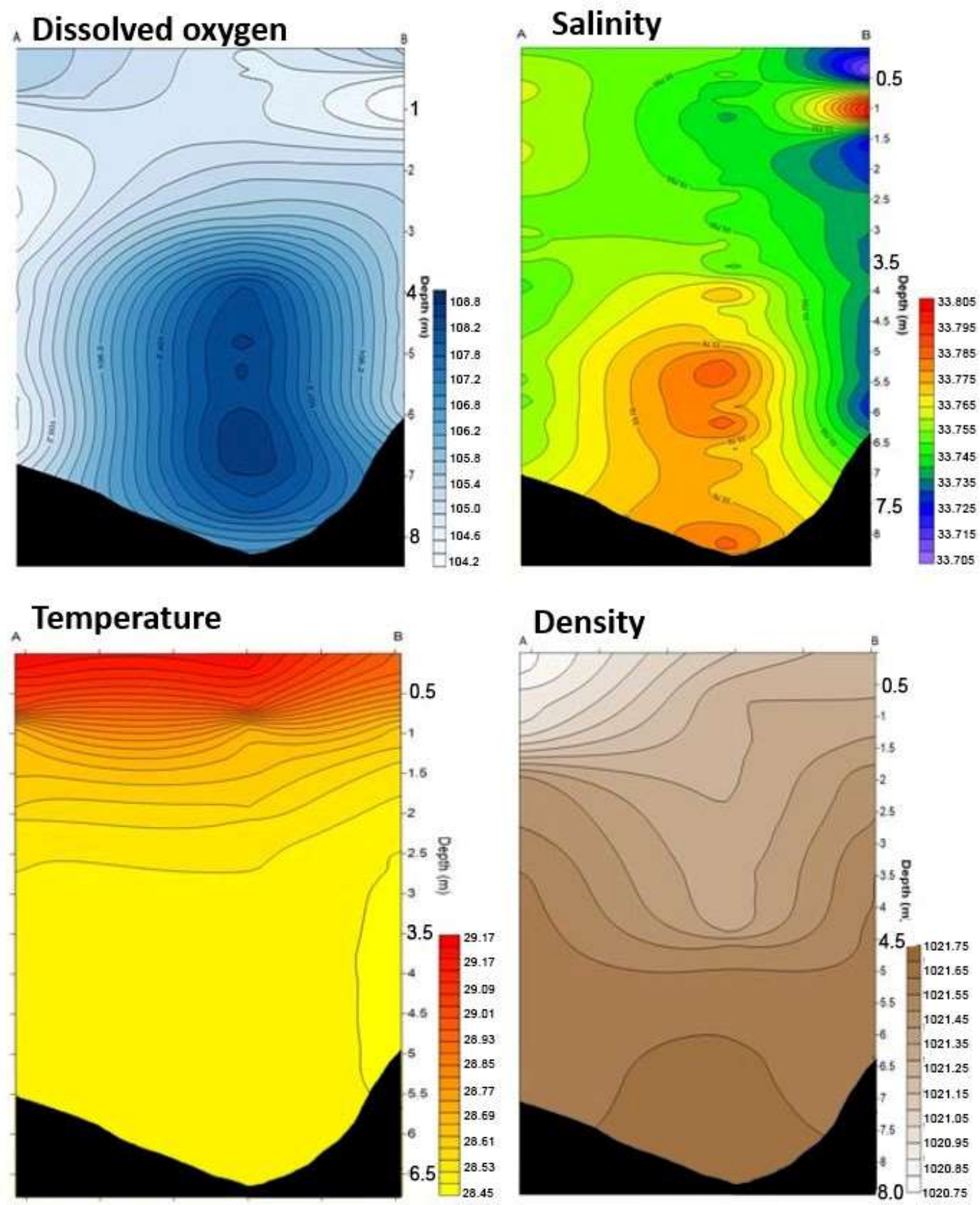

Fig. 5. The longshore survey profile along the deeper depth $(\mathrm{CD}$, including sampling sites P5, P8, and P17) shows physicochemical variations.

\section{SALINITY}

Salinity is usually measured as the total amount of dissolved salt in water. No clear salinity variations can be observed along the cross-shore survey line (Figure 6). However, salinity values gradually increase with depth along the shallow depth longshore survey line (Figure 4). Figure 5 shows that salinity values gradually increase towards southwest direction (from sampling site P17 to P5). The average salinity value of the study area is about 33 ppt. The salinity of the Tangalle Bay is just lower compared to the global average value of 35 ppt (e.g., Huber et al., 2000). It is followed by heavy rainfall and relatively high humidity, and a significant contribution of freshwater to equatorial seawater. 


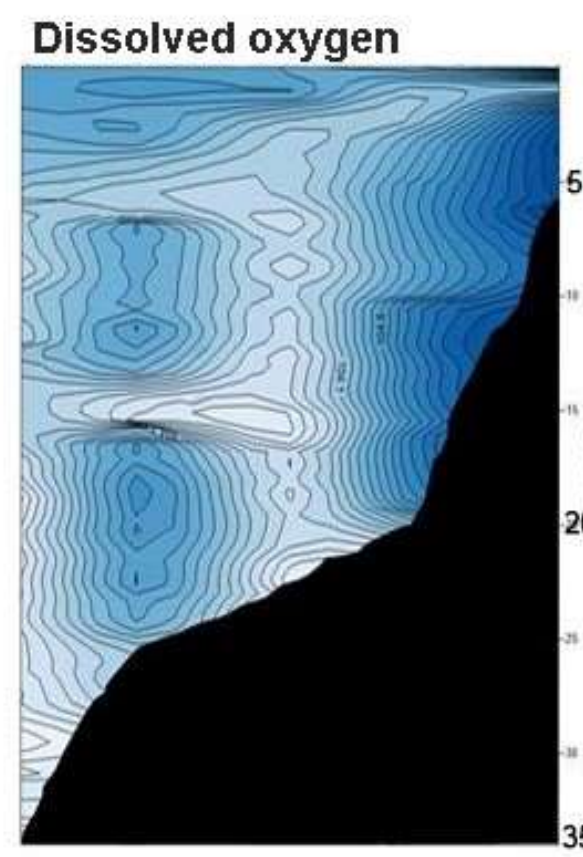

Temperature

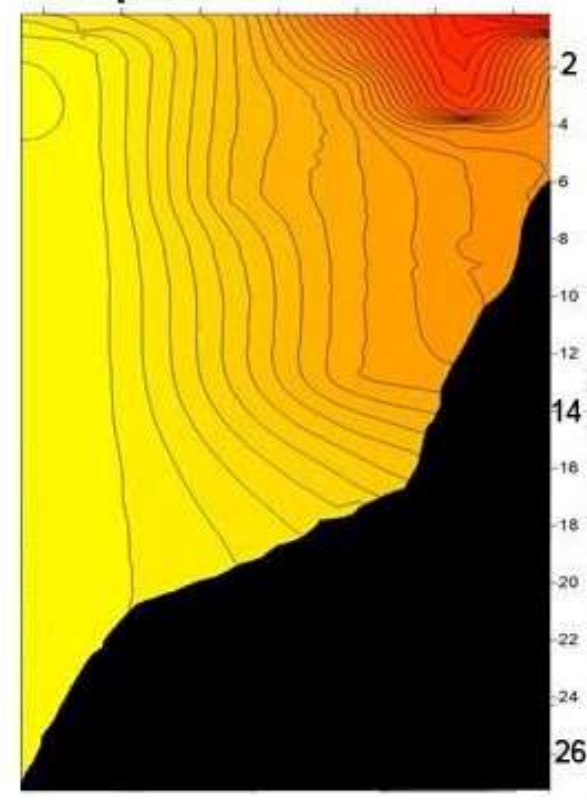

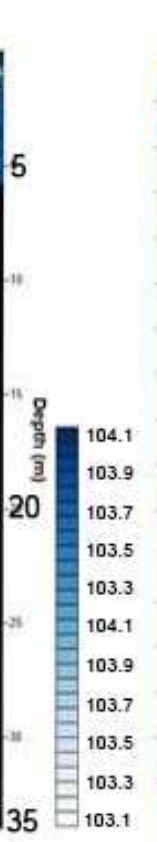

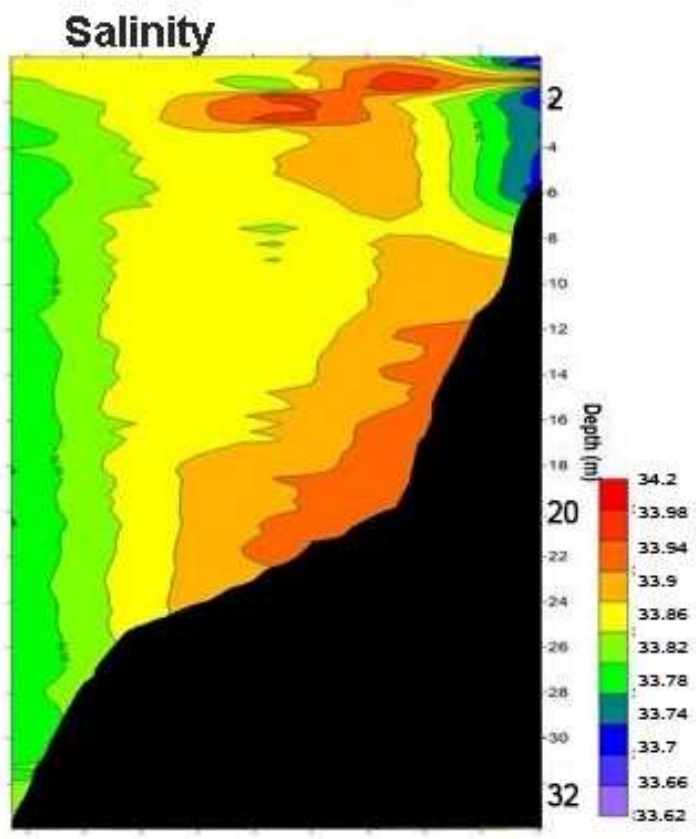

\section{Density}

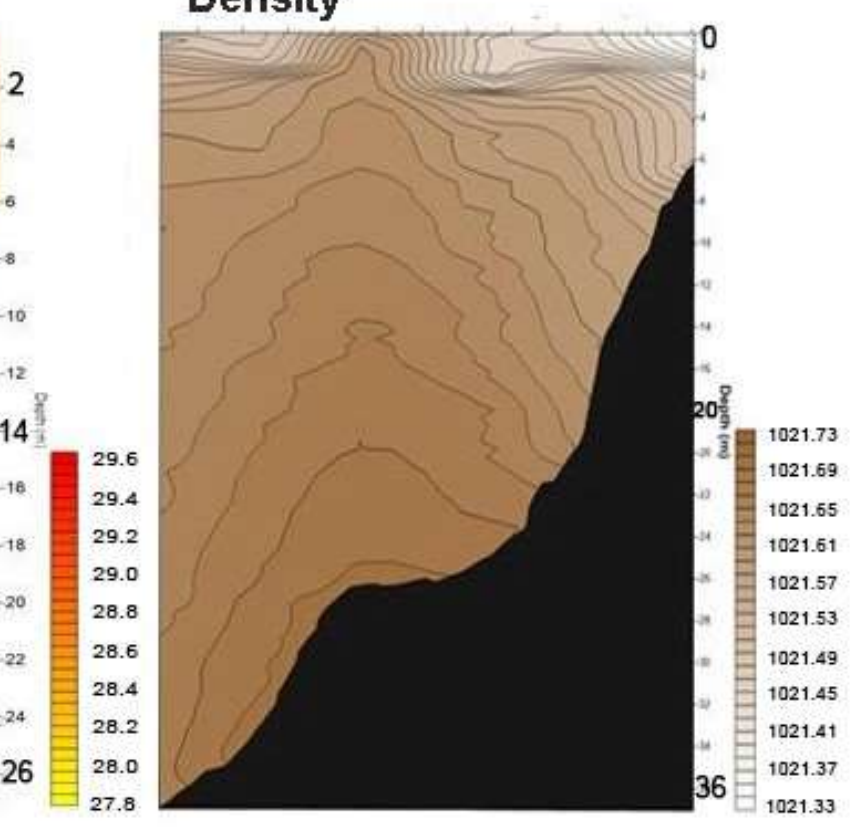

Fig. 6: The cross-shore survey profile (sampling sites from P1 to P6) shows physicochemical variations.

\section{DISSOLVED OXYGEN}

The oxygen exchanging process between the air-sea interfaces can be considered as one of the main physical factor to control the dissolved oxygen content in surface water (Liss, 1973; Broecker and Peng, 1974). In addition, oxygen enters the water column when entrained in bubbles from breaking waves. This process is independent of dissolved oxygen content (Broecker and Peng, 1982). In this study, dissolved oxygen values vary from 7.5 - $8.0 \mathrm{ppm}$, according to saturation level $100-108 \%$ at $30{ }^{\circ} \mathrm{C}$. Dissolved oxygen values are relatively high along the shallow depth longshore survey line (Figure 4). Figure 5 shows that dissolved oxygen values are quite high 
towards southwest direction (from sampling site P17 to P5). In addition, no systematic dissolved oxygen variations can be observed along the cross-shore survey line (Figure 6). However, the measured dissolved oxygen values are quite high for the equatorial marine condition. Dissolved oxygen content can be used to understand the quality of aquatic life, as it is a byproduct of photosynthesis and required a component of the respiration. Therefore, biological activities are controlled by dissolved oxygen level in the marine water (Redfield, 1958; Luz and Barkan, 2000).

Table 1. Summary of the maximum and minimum values of physical parameters of water in survey lines

\begin{tabular}{|c|c|c|c|c|c|c|}
\hline \multirow{3}{*}{$\begin{array}{l}\text { Physical } \\
\text { Parameters }\end{array}$} & \multicolumn{6}{|c|}{ Survey Lines } \\
\hline & \multicolumn{2}{|c|}{$\mathbf{A B}$} & \multicolumn{2}{|c|}{ CD } & \multicolumn{2}{|c|}{ BD } \\
\hline & $\begin{array}{l}\text { Minimu } \\
\text { m }\end{array}$ & $\begin{array}{l}\text { Maximu } \\
\text { m }\end{array}$ & $\begin{array}{l}\text { Minimu } \\
\text { m }\end{array}$ & $\begin{array}{l}\text { Maximu } \\
\text { m }\end{array}$ & $\begin{array}{l}\text { Minimu } \\
\text { m }\end{array}$ & $\begin{array}{l}\text { Maximu } \\
\text { m }\end{array}$ \\
\hline $\begin{array}{l}\text { Dissolved } \\
\text { oxygen (ppm) }\end{array}$ & 8.5 & 8.8 & 7.8 & 8.0 & 7.8 & 8.1 \\
\hline Salinity (ppt) & 33.71 & 33.81 & 33.42 & 33.62 & 33.62 & 34.40 \\
\hline $\begin{array}{l}\text { Temperature } \\
\left({ }^{0} \mathrm{c}\right)\end{array}$ & 28.45 & 29.17 & 27.80 & 28.00 & 27.80 & 29.60 \\
\hline Density $\left(\mathrm{kg} / \mathrm{m}^{3}\right)$ & $1,020.75$ & $1,021.75$ & $1,021.22$ & $1,021.62$ & $1,021.33$ & $1,021.73$ \\
\hline
\end{tabular}

\section{DENSITY}

Water density is controlled by temperature, salinity, and pressure (Millero, 2000; Smith, 2004). CTD instrument calculates water density using above mentioned controlling parameters. The calculated water density values of the Tangalle Bay range from $1020.7-1021.5 \mathrm{~kg} / \mathrm{m}^{3}$. The cross-shore and longshore survey lines indicate that the calculated water density of the Tangalle Bay is slightly increased with depth within a narrow range (Figures 4, 5 and 6). In contrast, the upwelling can be recognized as one of the major nutrient/density mixing and distribution processes in the marine environment (Macdonald et al., 1987). However, additional field excursions are required to identify seasonal changes of water quality parameters in the study area.

\section{CONCLUSION}

The echogram of the sub-bottom profiler data can be used to understand local geomorphological changes such as recorded in coral reef barriers and sediment dynamics/transportation patterns of the particular area. Such knowledge can be productively applied to design sustainable coastal engineering structures and monitor coastal environmental changes.

Physical properties of water in the study area show homogenous distributions with the little changes. Therefore, it is an indicator of wellmixed nature. In addition, water quality parameters show health aquatic system. The recorded water quality 
parameters can be used as baseline data for the future monitoring programs and pollution risk evaluations of the Tangalle Bay.

\section{ACKNOWLEDGMENT}

The authors wish to an extent their gratitude to Dr. H.M.R. Premasiri, Head of the Department, Earth Resources Engineering, all students of $12^{\text {th }}$ batch of Earth Resources Engineering, and technical staff members of Ms. Ranjini Amarasinghe and Mr. Sandun Silva for providing assistance and facilities towards making this project a success. This research was financially granted by SRC short term grant, (Grant No SRC/ST/2017/22) University of Moratuwa, Sri Lanka.

\section{REFERENCES}

Broecker, W. S., Peng, T. H. (1974) Gas exchange rates between air and sea. Tellus, 26 (1-2), 21-35.

Broecker, W.S., Peng, T.H. (1982) Tracers in the Sea.

Carton, J.A., Giese, B.S. (2008) A reanalysis of ocean climate using Simple Ocean Data Assimilation (SODA). Mon. Weather Rev. 136, 2999-3017.

Cooray, P.G. (1984) An introduction to the geology of Sri Lanka (Ceylon). National museums of Sri Lanka publication.

Dubois, N., Saulnier-Talbot, É., Mills, K., Gell, P., Battarbee, R., Bennion, H., Chawchai, S., Dong, X., Francus, P., Flower, R. (2018) First human impacts and responses of aquatic systems: A review of palaeolimnological records from around the world. Anthr. Rev. 5, 28-68.

Hedges, J. I., Keil, R. G. (1995) Sedimentary organic matter preservation: an assessment and speculative synthesis. Marine chemistry, 49(2-3), 81-115.

Huber, C., Klimant, I., Krause, C., Werner, T., Mayr, T., Wolfbeis, O.S. (2000) Optical sensor for seawater salinity. Fresenius. J. Anal. Chem. 368, 196-202.

Jayawardana, D.T., Ishiga, H., Pitawala, H. (2012) Geochemistry of surface sediments in tsunami-affected Sri Lankan lagoons regarding environmental implications. Int.
J. Environ. Sci. Technol. 9, 41-55.

Kirwan, M.L., Megonigal, J.P. (2013) Tidal wetland stability in the face of human impacts and sea-level rise. Nature 504, 53.

Liss, P. S. (1973) Processes of gas exchange across an air-water interface. In Deep Sea Research and Oceanographic Abstracts (Vol. 20, No. 3, pp. 221-238). Elsevier.

Luz, B., Barkan, E. (2000) Assessment of oceanic productivity with the tripleisotope composition of dissolved oxygen. Science, 288 (5473), 2028-2031.

Macdonald, R. W., Wong, C. S., Erickson, P. E. (1987) The distribution of nutrients in the southeastern Beaufort Sea: Implications for water circulation and primary production. Journal of Geophysical Research: Oceans, 92 (C3), 2939-2952.

Millero, F. J. (2000) Effect of changes in the composition of seawater on the densitysalinity relationship. Deep Sea Research Part I: Oceanographic Research Papers, 47(8), 1583-1590.

Müller, P. J., Suess, E. (1979) Productivity, sedimentation rate, and sedimentary organic matter in the oceans-I. Organic carbon preservation. Deep Sea Research Part A. Oceanographic Research Papers, 26(12), 1347-1362.

Nicholls, R.J., Cazenave, A. (2010) Sea-level rise and its impact on coastal zones. Science (80-. ). 328, 1517-1520.

Rajasuriya, A., White, A.T. (1995) Coral reefs of Sri Lanka: Review of their extent, condition, and management status. Coast. Manag. 23, 77-90.

Ratnayake, A.S., Dushyantha, N., De Silva, N., Somasiri, H.P., Jayasekara, N.N., Weththasinghe, S.M., Samaradivakara, G.V.I., Vijitha, A.V.P., Ratnayake, N.P. (2017a) Sediment and physicochemical characteristics in Madu-ganga Estuary, southwest Sri Lanka. J. Geol. Soc. Sri Lanka 18, 43-52.

Ratnayake, A.S., Ratnayake, N.P., Sampei, Y., Vijitha, A.V.P., Jayamali, S.D. (2018a) Seasonal and tidal influence for water quality changes in coastal Bolgoda Lake system, Sri Lanka. J Coast Conserv.

Ratnayake, A.S., Sampei, Y., Ratnayake, N.P., Roser, B.P. (2017b) Middle to late Holocene environmental changes in the depositional system of the tropical brackish Bolgoda Lake, coastal southwest Sri Lanka. Palaeogeogr. Palaeoclimatol. Palaeoecol. 465, 122-137.

Ratnayake, N.P., Ratnayake, A.S., Keegle, P. V, Arachchi, M.M., Premasiri, H.M.R. (2018b) An analysis of beach profile 
changes subsequent to the Colombo Harbor Expansion Project, Sri Lanka. Environ. Earth Sci. 77, 24.

Ratnayake, N.P., Silva, K.B.A., Kumara, I. (2013) Chloride contamination in construction aggregates due to periodic saline water intrusion: a case study in the Kaluganga River Estuary, Sri Lanka. Environ. Earth Sci. 69, 2529-2540.

Redfield, A. C. (1958) The biological control of chemical factors in the environment. American scientist, 46(3), 230A-221.

Sampei, Y., Matsumoto, E., Tokuoka, T., Inoue, D. (1997) Changes in accumulation rate of organic carbon during the last 8000 years in sediments of Nakaumi Lagoon, Japan. Mar Chem 58, 39-50.

Seibold, E., Berger, W. H. (1996) Sources and
Composition of Marine Sediments. In The Sea Floor (pp. 69-95). Springer, Berlin, Heidelberg.

Smith, A. J. (2004) Mixed convection and density-dependent seawater circulation in coastal aquifers. Water Resources Research, 40(8).

Van Rijn, L.C. (2011) Coastal erosion and control. Ocean Coast. Manag. 54, 867887.

Zhou, L., Liu, J., Saito, Y., Zhang, Z., Chu, H., $\mathrm{Hu}$, G. (2014) Coastal erosion as a major sediment supplier to continental shelves: example from the abandoned Old Huanghe (Yellow River) delta. Cont. ShelfRes.82,43-59. 